Jurnal InFestasi

Vol. 12, No.2, Desember 2016

Hal. $158-172$

\title{
FAKTOR-FAKTOR YANG MEMPENGARUHI KUALITAS LAPORAN KEUANGAN DAN AKUNTABILITAS KINERJA INSTANSI PEMERINTAH (STUDI EMPIRIS PADA SATKER BALAI BESAR BMKG WILAYAH III DENPASAR-BALI)
}

\author{
Santha Julia Sardi ${ }^{1}$ \\ H. Ahmad Rifa'i ${ }^{2}$ \\ L. Hamdani Husnan² \\ ${ }^{1}$ Stasiun Meteorologi Selaparang-Bandara Internasional Lombok \\ 2 Fakultas Ekonomi dan Bisnis, Universitas Mataram, NTB, Indonesia \\ ithasardi@gmail.com, telp : +62 81803614911
}

\begin{abstract}
This study aims to examine empirically the effect of the influence of Clarity Target Budget, Internal Control Systems, Human Resources and Government Accounting Standards on Financial Statement Quality and Accountability Government Performance. The population was 366 respondents KPA / PPK and treasurer at 183 work units BMKG. The number of samples is determined by purposive sampling technique, resulting in a sample of 94 respondents consisting of 47 units working under the coordination of the Center for BMKG Region III Denpasar-Bali. Collecting data using primary data by distributing questionnaires. Data analysis tool used is Partial Least Square (PLS). Tests on the research done by using second order confirmatory factor analysis. The findings of this study indicate that: (1) Quality of Financial Statements significantly affected by Goal Clarity Budget and Government Accounting Standards, but was not significantly affected by SPI and natural resources; (2) Accountability of Government Performance is significantly affected by SPI and SAP, but was not significantly affected by Goal Clarity Budget and Human Resources; (3) Quality of Financial Statements significantly influence the Government Performance Accountability. The implications of this study may be useful as consideration for decision makers in improving the quality of financial statements and Accountability Government Performance as a form of state financial management.
\end{abstract}

Keywords : Clarity Target Budget, Internal Control Systems, Human Resources, Government Accounting Standards, Quality Report Performance and Accountability of Government Performance

\begin{abstract}
Abstrak
Penelitian ini bertujuan menguji secara empiris pengaruh pengaruh Kejelasan Sasaran Anggaran, Sistem Pengendalian Intern, Sumber Daya Manusia dan Standar Akuntansi Pemerintahan terhadap Kualitas Laporan Keuangan dan Akuntabilitas Kinerja Instansi Pemerintah. Populasi penelitian ini adalah 366 responden KPA/PPK dan bendahara pengeluaran pada 183 satuan kerja BMKG. Jumlah sampel ditentukan dengan teknik purposive sampling, sehingga menghasilkan sampel sejumlah 94 responden yang terdiri atas 47 satuan kerja dibawah koordinasi Balai Besar BMKG Wilayah III Denpasar-Bali. Pengumpulan data menggunakan sumber data primer melalui penyebaran kuesioner. Alat analisis data yang digunakan adalah Partial Least Square (PLS). Pengujian pada penelitian ini dilakukan dengan menggunakan second order confirmatory factor analysis. Temuan penelitian ini menunjukkan bahwa : (1) Kualitas Laporan Keuangan dipengaruhi secara signifikan oleh Kejelasan Sasaran Anggaran dan Standar Akuntansi Pemerintahan, tetapi tidak dipengaruhi secara signifikan oleh SPI dan SDM; (2) Akuntabilitas Kinerja Instansi Pemerintah dipengaruhi secara signifikan oleh SPI dan SAP, tetapi tidak dipengaruhi secara signifikan oleh Kejelasan Sasaran Anggaran dan SDM; (3) Kualitas Laporan Keuangan berpengaruh secara signifikan terhadap Akuntabilitas Kinerja Instansi
\end{abstract}


Santha J. S., H. A. Rifa'i, L. Hamdani H. Jurnal InFestasi Vol.12, No.2, Desember 2016

Pemerintah. Implikasi penelitian ini dapat berguna sebagai pertimbangan bagi para pengambil keputusan dalam usaha peningkatan Kualitas Laporan Keuangan dan Akuntabilitas Kinerja Instansi Pemerintah sebagai bentuk pertanggungjawaban pengelolaan keuangan negara.

Kata Kunci : Kejelasan Sasaran Anggaran, Sistem Pengendalian Intern, Sumber Daya Manusia, Standar Akuntansi Pemerintahan, Kulaitas Laporan Keuangan dan Akuntabilitas Kinerja Instansi Pemerintah.

\section{PENDAHULUAN}

Akuntabilitas pemerintah dapat dilihat dari dua bagian, yaitu Akuntabilitas keuangan merupakan pertanggungjawaban mengenai integritas keuangan, pengungkapan, dan ketaatan terhadap peraturan perundangundangan. Sasaran pertanggungjawaban adalah laporan keuangan yang disajikan dan peraturan perundang-undangan yang berlaku yang mencakup penerimaan, penyimpanan dan pengeluaran uang oleh isnstansi pemerintah (LAN dan BPKP, 2000:28). Sedangkan akuntabilitas kinerja adalah kewajiban untuk memberikan pertanggungjawaban atau menjawab dan menerangkan kinerja dan tindakan seorang/badan hukum/pimpinan/suatu organisasi kepada pihak yang meiliki hak atau kewenangan untuk meminta keterangan atau pertanggungjawaban (LAN dan BPKP, 2000:43).

Penyusunan laporan keuangan yang berpedoman pada standar akuntansi pemerintah bermanfaat untuk pemenuhan kebutuhan informasi keuangan secara umum yang lebih berkualitas bagi para pengguna laporan keuangan dalam rangka menilai akuntabilitas dan membuat keputusan ekonomi, sosial maupun politik (Santoso dan Pambelum, 2008). Penerapan akuntansi keuangan sektor publik memberikan sumbangan bagi peningkatan akuntabilitas kinerja instansi pemerintah dalam hal penyajian informasi mengenai tujuan, fungsi, dan objek pengeluaran (Pamungkas, 2012).

Laporan akuntabilitas kinerja menurut Instruksi Presiden Nomor 7 Tahun 1999 laporan Akuntabilitas Kinerja Instansi Pemerintah adalah dokumen yang berisi gambaran perwujudan sistem Akuntabilitas Kinerja Instansi Pemerintah (SAKIP) yang dikembangkan secara terintegrasi dengan sistem perencanaan, sistem penganggaran, sistem perbendaharaan, dan Sistem Akuntansi Pemerintahan yang disampaikannya kepada Menteri Keuangan, Menteri Negara Perencanaan Pembangunan Nasional, dan Menteri Negara Pendayagunaan Aparatur NegaraReformasi Birokrasi yang selanjutnya dilakukan evaluasi dan penilaian oleh Menteri Negara Pendayagunaan Aparatur Negara-Reformasi Birokrasi.

Dalam Laporan BPK Nomor 45a/LHP/XV/05/2013 tanggal 20 Mei 2013, BPK memberikan opini Wajar Dengan Pengecualian (WDP) atas Laporan Keuangan Pemerintah Pusat Tahun 2012 salah satunya karena kelemahan dalam penganggaran dan penggunaan anggaran Belanja Barang, Belanja Modal, dan Belanja Bantuan Sosial dan atas pelaksanaan revisi Daftar Isian Pelaksanaan Anggaran (DIPA). Laporan Hasil Pemeriksaan BPK RI atas laporan keuangan pemerintah BMKG tahun 2014 menunjukkan masih terdapat temuan terkait anggaran dan pelaksanaannya yaitu Pengelompokan jenis belanja pada saat penganggaran tidak sesuai dengan kegiatan yang dilakukan, dan temuan ketidakhematan yang diungkapkan sebagai penggunaan input dengan harga atau kuantitas/kualitas yang lebih tinggi dari standar kuantitas/ kualitas yang melebihi kebutuhan, dan harga yang lebih mahal dibandingkan dengan pengadaan serupa pada waktu yang sama.

Akuntabilitas segi keuangan dan akuntabilitas segi kinerja mempunyai hubungan yang kuat dengan pengelolaan keuangan dan anggaran negara karena laporan akuntabilitas kinerja instansi pemerintah dibuat berdasarkan laporan keuangan sesuai yang diamatkan dalam PP Nomor 8 tahun 2006. Santoso dan Pambelum (2008), Pamungkas (2012), 
Santha J. S., H. A. Rifa'i, L. Hamdani H. Jurnal InFestasi Vol.12, No.2, Desember 2016

Darwanis dan Chairunnisa (2013) yang menunjukkan bahwa penerapan akuntansi sektor publik dan laporan keuangan yang berkualitas berpengaruh signifikan terhadap akuntabilitas kinerja instansi pemerintah. Sedangkan penelitian Asmoko (2012) menunjukkan tidak ada hubungan yang signifikan antara opini audit BPK atas LKKL dan hasil evaluasi LAKIP K/L.

Bentuk pertanggungjawaban organisasi sektor publik mencerminkan keadaan organisasi tersebut, untuk itu diperlukan suatu penelitian tentang usaha organisasi sektor publik dalam mempertanggungjawabkan pengelolaan keuangan negara kedalam laporan pertanggungjawaban keuangan dan kinerja. Berdasarkan uraian latar belakang di atas, maka penulis tertarik untuk melakukan penelitian dengan judul "Faktor-Faktor yang Mempengaruhi Kualitas Laporan Keuangan dan Akuntabilitas Kinerja Instansi Pemerintah (Studi Empiris pada satuan kerja BMKG Balai Besar Wilayah III Denpasar - Bali)"

Berdasarkan penjelasan tersebut di atas, maka permasalahan yang akan dibahas melalui penelitian ini adalah: (1) Apakah Kejelasan Sasaran Anggaran, SPI, SDM dan SAP berpengaruh terhadap Kualitas Laporan Keuangan dan Akuntabilitas Kinerja Instansi Pemerintah ? , dan (2) Apakah Kualitas Laporan Keuangan berpengaruh terhadap Akuntabilitas Kinerja Instansi Pemerintah?

\section{Good Governance}

Good Governance sering diartikan sebagai kepemerintahan yang baik. Good Governance lebih ditekankan kepada proses, sistem, prosedur dan peraturan yang formal ataupun informal yang menata organisasi dimana aturan main yang ada diterapkan dan ditaati. Good Governance berorientasi kepada penciptaan keseimbangan antara tujuan ekonomis dan sosial atau antara tujuan individu dan masyarakat (banyak orang) yang diarahkan kepada peningkatan efisiensi dan efektifitas dalam hal pemakaian sumber daya organisasi sejalan dengan tujuan organisasi.
Reformasi

kelembagaan menyangkut pembenahan seluruh alatalat pemerintah baik struktur maupun infrastrukturnya. Kemudian untuk mendukung terjadinya good governance, maka diperlukan serangkaian reformasi lanjutan selain reformasi kelembagaan dan reformasi manajemen sektor publik, terutama yang terkait dengan sistem pengelolaan keuangan pemerintah, yaitu: (1) Reformasi Sistem Penganggaran (budgeting reform), (2) Reformasi Sistem Akuntansi (accounting reform), (3) Reformasi Sistem Pemeriksaan (audit reform), dan (4). Reformasi Sistem Manajemen Keuangan (financial management reform). Lebih lanjut Mardiasmo (2009) menjelaskan bahwa dalam memberikan layanan kepada masyarakat, pemerintah dituntut lebih responsif atau cepat dan tanggap, transparan, dan akuntabel.

\section{Teori Keagenan (Agency Theory)}

Jensen dan Meckling (1976) mendefinisikan hubungan keagenan sebagai sebuah kontrak dimana satu atau lebih (principal) menyewa orang lain (agent) untuk melakukan beberapa jasa untuk kepentingan principal. Pada dasarnya organisasi sektor publik dibangun atas dasar agency theory. Hubungan antara pemerintah dan masyarakat dapat digambarkan sebagai suatu hubungan keagenan (agency relationship), dalam hal ini pemerintah berfungsi sebagai agen yang diberi kewenangan untuk melaksanakan kewajiban tertentu yang ditentukan oleh masyarakat sebagai prinsipal, baik secara langsung atau tidak langsung melalui wakil-wakilnya. Dalam hubungan keagenan, pemerintah sebagai agen harus melaksanakan apa yang menjadi kepentingan masyarakat sebagai prinsipalnya. Hubungan antara pemerintah dan masyarakat dengan demikian merupakan sebuah hubungan pertanggungjawaban, dalam hal ini pemerintah sebagai agen harus mempertanggungjawabkan aktivitas dan kinerjanya kepada masyarakat yang telah memberikan dana (public fund) kepada pemerintah. Pertanggungjawaban kepada masyarakat ini disebut akuntabilitas publik (Mahmudi, 2013:8). 
Santha J. S., H. A. Rifa'i, L. Hamdani H. Jurnal InFestasi Vol.12, No.2, Desember 2016

\section{Pengaruh Kejelasan Sasaran Anggaran terhadap Laporan Keuangan dan Akuntabilitas Kinerja Instansi Pemerintah}

Menurut Nugraha (2007) parameter tercapai tidaknya sasaran suatu organisasi sektor publik dapat menggunakan parameter berikut : (a)Dapat diukur ;(b) Sesuai dengan prioritas ; dan (c) Memberikan manfaat optimum, Penelitian yang dilakukan Verbeeten (2008) yang menunjukkan bahwa sasaran anggaran yang jelas dan terukur dapat secara signifikan meningkatkan kinerja baik secara kuantitas maupun kualitas. Indudewi (2009), Kusumaningrum (2010), Karyanti (2010), Putra (2013) dan Nuraini serta Indudewi (2014) juga menyatakan Kejelasan Sasaran Anggaran, berpengaruh positif dan signifikan terhadap Akuntabilitas Kinerja Instansi Pemerintah. Namun hasil yang berbeda dengan penelitian Darwanis dan Chairunnisa (2013) pada pemerintah propinsi Aceh dengan hasil bahwa Kejelasan Sasaran Anggaran berpengaruh tidak signifikan terhadap Akuntabilitas Kinerja Instansi Pemerintah.

Berdasarkan latar belakang, perumusan masalah, dan uraian pada peneliti terdahulu maka dalam penelitian ini dapat diajukan hipotesis sebagai berikut:

$\begin{array}{lcr}\text { H1: Kejelasan } & \text { Sasaran } & \text { Anggaran } \\ \text { berpengaruh } & \text { terhadap } & \text { Kualitas } \\ & \text { Laporan Keuangan. } & \end{array}$

H2: Kejelasan Sasaran Anggaran berpengaruh terhadap Akuntabilitas Kinerja Instansi Pemerintah.

\section{Pengaruh Sistem Pengendalian Intern terhadap Laporan Keuangan dan Akuntabilitas Kinerja Instansi Pemerintah}

Penelitian terdahulu tentang Sistem Pengendalian Intern dalam hubungannya dengan kualitas laporan keuangan dan akuntabilitas kinerja yaitu penelitian kualitatif Atyanta (2012) yang menunjukkan bahwa opini WDP dari BPK yang diberikan terhadap beberapa LKPD Kabupaten di Jawa Timur disebabkan adanya temuan kasus Ketidakefektifan
SPI. Penelitian Indriasari (2008), Sukmaningrum (2011), Yudianta dan Erawati (2012), Pamungkas (2012) Armando (2013), dan Darwanis dan Chairunnisa (2013) yang menunjukkan bahwa SPIP dan pengawasan keuangan berpengaruh signifikan terhadap nilai informasi laporan keuangan pemerintah. Sedangkan penelitian Arifianti (2011) yang dilakukan pada SKPD kabupaten Batang dengan hasil bahwa sistem pengendalian intern tidak berpengaruh signifikan terhadap nilai pelaporan keuangan pemerintah. Kusumaningrum (2010), Nasir dan Oktari (2013), Kogulacumar (2013) dan Nuraini serta Indudewi (2014) yang menyatakan bahwa SPI berpengaruh terhadap Akuntabilitas Kinerja Instansi Pemerintah (AKI) namun berbeda dengan hasil penelitian Ajhar (2015) yang menyatakan bahwa SPI tidak berpengaruh terhadap Akuntabilitas Kinerja Instansi Pemerintah (AKI). Berdasarkan latar belakang, perumusan masalah, dan uraian pada peneliti terdahulu, maka dalam penelitian ini dapat diajukan hipotesis sebagai berikut:

H3: Sistem Pengendalian Intern berpengaruh terhadap Kualitas Laporan Keuangan.

$\begin{array}{llr}\text { H4: } & \begin{array}{l}\text { Sistem Pengendalian } \\ \text { berpengaruh }\end{array} & \begin{array}{l}\text { Intern } \\ \text { terhadap }\end{array} \\ \text { Akuntabilitas Kinerja } & \text { Instansi } \\ \text { Pemerintah. } & & \end{array}$

Pengaruh Sumber Daya Manusia terhadap Laporan Keuangan dan Akuntabilitas Kinerja Instansi Pemerintah

Peranan sumber daya manusia akan sangat menentukan keberhasilan atau kegagalan organisasi dalam mencapai tujuan, visi dan misi yang telah ditetapkan baik pada organisasi publik maupun private (Sudarmanto, 2014).

Penelitian Arifianti (2011) yang menyatakan kualitas sumber daya manusia berpengaruh terhadap nilai pelaporan keuangan pemerintah daerah. Yudianta dan Erawati (2012) yang menyatakan bahwa SDM berpengaruh terhadap Kualitas Laporan Keuangan (KLK), sedangkan penelitian yang dilakukan Indriasari (2008), dan Sukmaningrum (2011) menyatakan Sumber Daya Manusia tidak 
Santha J. S., H. A. Rifa'i, L. Hamdani H. Jurnal InFestasi Vol.12, No.2, Desember 2016

berpengaruh terhadap Kualitas Laporan Keuangan. Gistyan (2014) menunjukkan kompetensi pegawai berpengaruh terhadap akuntabilitas kinerja instansi pemerintah. Sedangkan Ajhar (2015) yang menyatakan bahwa SDM tidak berpengaruh terhadap Akuntabilitas Kinerja Instansi Pemerintah daerah kabupaten Dompu. Berdasarkan latar belakang, perumusan masalah, dan uraian pada peneliti terdahulu, maka dalam penelitian ini dapat diajukan hipotesis sebagai berikut :

H5: Sumber Daya Manusia berpengaruh terhadap Kualitas Laporan Keuangan.

H6: Sumber Daya Manusia berpengaruh terhadap Akuntabilitas Kinerja Instansi Pemerintah.

Pengaruh Standar Akuntansi Pemerintah terhadap Laporan Keuangan dan Akuntabilitas Kinerja Instansi Pemerintah

Menurut Peraturan Pemerintah Nomor 71 tahun 2010 tentang Standar Akuntansi Pemerintahan Akuntansi adalah proses identifikasi, pencatatan, pengukuran, pengklasifikasian, pengikhtisaran transaksi dan kejadian keuangan, penyajian laporan, serta penginterpretasian atas hasilnya. Standar Akuntansi Pemerintahan, yang selanjutnya disingkat SAP, adalah prinsip-prinsip akuntansi yang diterapkan dalam menyusun dan menyajikan laporan keuangan pemerintah.

Dengan diterapkannya SAP, diharapkan terwujudnya transparansi, partisipasi dan akuntabilitas pengelolaan keuangan negara guna mewujudkan pemerintahan yang baik (good governance). Dalam Peraturan Pemerintah Nomor 71 tahun 2010 tentang Standar Akuntansi Pemerintahan Akuntansi berikut ini adalah delapan prinsip yang digunakan dalam akuntansi dan pelaporan keuangan pemerintah : (a) Basis akuntansi; (b) Prinsip nilai historis; c) Prinsip realisasi; Prinsip substansi mengungguli bentuk formal; (e) Prinsip periodisitas; (f) Prinsip konsistensi; (g) Prinsip pengungkapan lengkap; dan (h) Prinsip penyajian wajar.
Penelitian terdahulu dilakukan
Santoso dan Pambelum (2008),
Nugraheni dan Subaweh (2008), Zeyn
(2011) dan Pamungkas (2012) menyatakan bahwa bahwa Penerapan SAP berpengaruh positif terhadap kualitas laporan keuangan dan akuntabilitas kinerja instansi pemerintah. Berdasarkan latar belakang, perumusan masalah, dan uraian pada peneliti terdahulu maka dalam penelitian ini dapat diajukan hipotesis sebagai berikut :

H7: Standar Akuntansi Pemerintah berpengaruh terhadap Kualitas Laporan Keuangan.

H8: Standar Akuntansi Pemerintah berpengaruh terhadap Akuntabilitas Kinerja Instansi Pemerintah.

\section{Pengaruh Kualitas Laporan Keuangan dan Akuntabilitas Kinerja Instansi \\ Pemerintah}

Laporan keuangan disusun untuk menyediakan informasi yang relevan mengenai posisi keuangan dan seluruh transaksi yang dilakukan oleh suatu entitas pelaporan selama satu periode pelaporan. Setiap entitas pelaporan mempunyai kewajiban untuk melaporkan upaya-upaya yang telah dilakukan serta hasil yang dicapai dalam pelaksanaan kegiatan secara sistematis dan terstruktur pada suatu periode pelaporan.

Penelitian Santoso dan Pambelum (2008), Pamungkas (2012), Darwanis dan Chairunnisa (2013) yang menunjukkan bahwa penerapan akuntansi sektor publik dan laporan keuangan yang berkualitas berpengaruh signifikan terhadap akuntabilitas kinerja instansi pemerintah. Sedangkan penelitian Asmoko (2012) menunjukkan tidak ada hubungan yang signifikan antara opini audit BPK atas LKKL dan hasil evaluasi LAKIP K/L. Berdasarkan latar belakang, perumusan masalah, dan uraian pada peneliti terdahulu serta rerangka konseptual penelitian, maka dalam penelitian ini dapat diajukan hipotesis sebagai berikut : 
Santha J. S., H. A. Rifa'i, L. Hamdani H. Jurnal InFestasi Vol.12, No.2, Desember 2016

H9: Kualitas Laporan Keuangan berpengaruh Akuntabilitas Kinerja Instansi Pemerintah.

\section{METODE PENELITIAN}

\section{Populasi dan Sampe1}

Teknik pengambilan sampel adalah purposive sampling sehingga sampel penelitian ini adalah KPA/PPK dan bendahara satuan kerja dibawah koordinasi Balai Besar Wilayah III Denpasar Bali sebanyak 94 responden dari 47 satuan kerja. Pengujian dilakukan pada 94 responden yang mewakili 25,7 persen populasi.

\section{Variabel Penelitian}

Variabel Laten/Konstruk dalam penelitian ini dibagi menjadi 2 (dua) yaitu variabel laten eksogen yang terdiri atas Kejelasan Sasaran Anggaran (KSA),Sistem Pengendalian Intern (SPI), Sumber Daya Manusia (SDM) dan Standar Akuntansi Pemerintahan (SAP) serta variabel laten endogen terdiri atas Kualitas Laporan Keuangan (KLK) dan Akuntabilitas Kinerja Instansi Pemerintah (AKI). Variabel manifest/teramati/indikator dalam penelitian ini berjumlah 64 yang terdiri dari Variabel laten KSA berjumlah 12, variabel laten SPI berjumlah 10, variabel laten SDM berjumlah 6, variabel laten SAP berjumlah 16, variabel laten KLK berjumlah 8 dan AKI berjumlah 12 .

\section{Analisis Data}

Statistik deskriptif adalah statistik yang digunakan untuk menganalisis data dengan cara mendiskripsikan atau menggambarkan data yang telah terkumpul sebagaimana adanya tanpa bermaksud membuat kesimpulan yang berlaku untuk umum atau generalisasi (Sugiyono, 2013:147).Statistik inferensial adalah teknik statistik yang digunakan untuk menganalisis data sampel dan hasilnya diberlakukan untuk populasi (Sugiyono, 2013: 148). Analisis data statistik inferensial diukur dengan menggunakan alat analisis PLS (SEMPLS).

\section{Model Analisis Struktural Awal}

Model analisis persamaan struktural menjelaskan hubungan antara variabel dan item. Gambar model persamaan analisis struktural awal dapat dilihat pada Gambar di bawah ini :

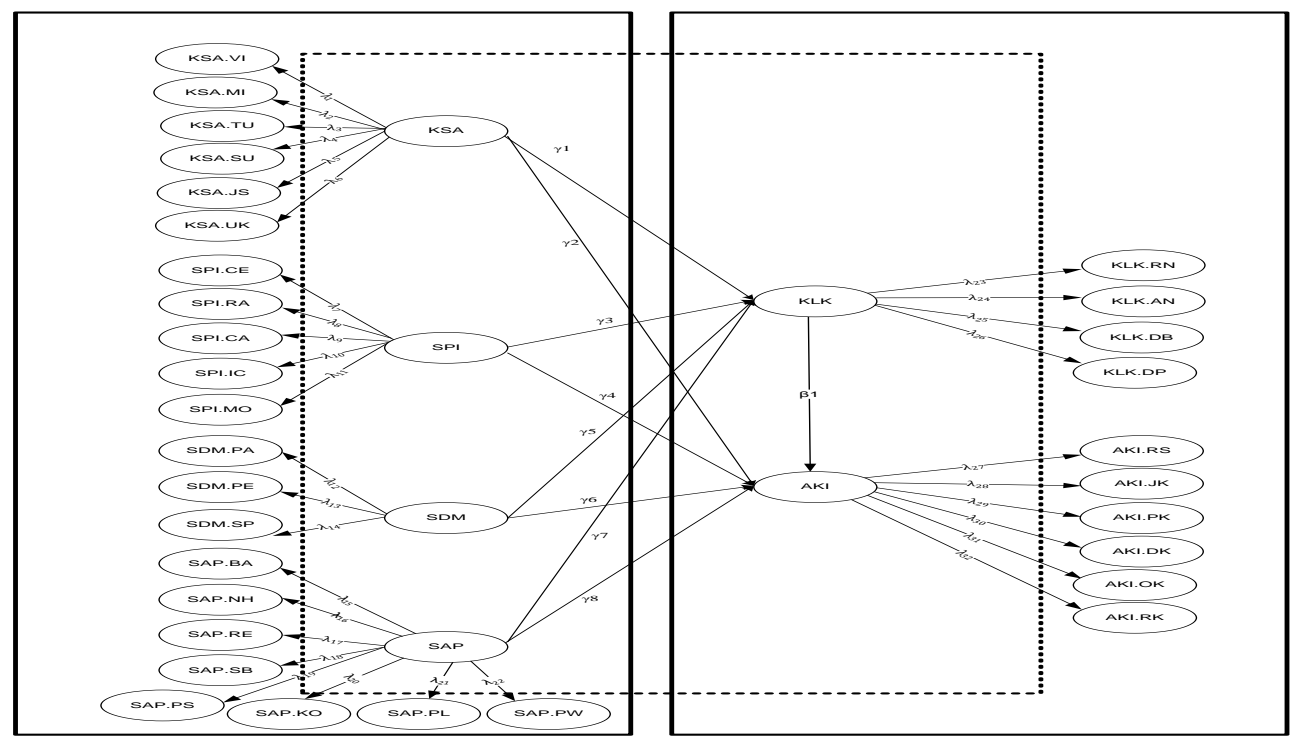

\section{Model Pengukuran (Outer Model)} Uji Validitas

Uji validitas dilakukan untuk mengetahui kemampuan instrumen penelitian mengukur konsistensi alat dalam mengukur apa yang seharusnya diukur (Cooper et al., 2006 dalam Jogiyanto, 2011:69). Uji validitas yang digunakan 
Santha J. S., H. A. Rifa'i, L. Hamdani H. Jurnal InFestasi Vol.12, No.2, Desember 2016

dalam penelitian ini yaitu Convergent validity dan Discriminant validity.

\section{Uji Reliabilitas}

Uji reliabilitas untuk mengukur konsistensi internal alat ukur. Reliabilitas menunjukkan akurasi, konsistensi, dan ketepatan suatu alat ukur dalam melakukan pengukuran. Uji reliabilitas dalam PLS dapat menggunakan 2 metode, yaitu Composite Reliability dan Cronbach's Alpha (Jogiyanto, 2011:72).

\section{Model Struktural (Inner Model) Pengujian Hipotesis}

Pengujian hipotesis dilakukan dengan membandingkan nilai T-table dengan nilai $T$-statistics yang dihasilkan dari proses bootstraping dalam PLS. Hipotesis diterima (terdukung) jika nilai $T$-Statistics lebih tinggi daripada nilai T-table $(1,66)$ dengan signifikansi level 10\% (two tailed) (Latan dan Ghozali, 2012:85).

\section{PEMBAHASAN}

\section{Model Pengukuran (Outer Model) Convergent Validity}

Analisis dilakukan 2 kali terhadap model, ada beberapa indikator yang di drop dari model karena memiliki nilai loading factor $<$ 0,7, untuk First Order Konstruk yaitu MI2, JS2, SB2, PS2, dan KO1 sedangkan untuk Second Order Konstruk SU, PL dan $\mathrm{KO}$, sehingga model pengukuran awal berubah menjadi pada Gambar 1 .

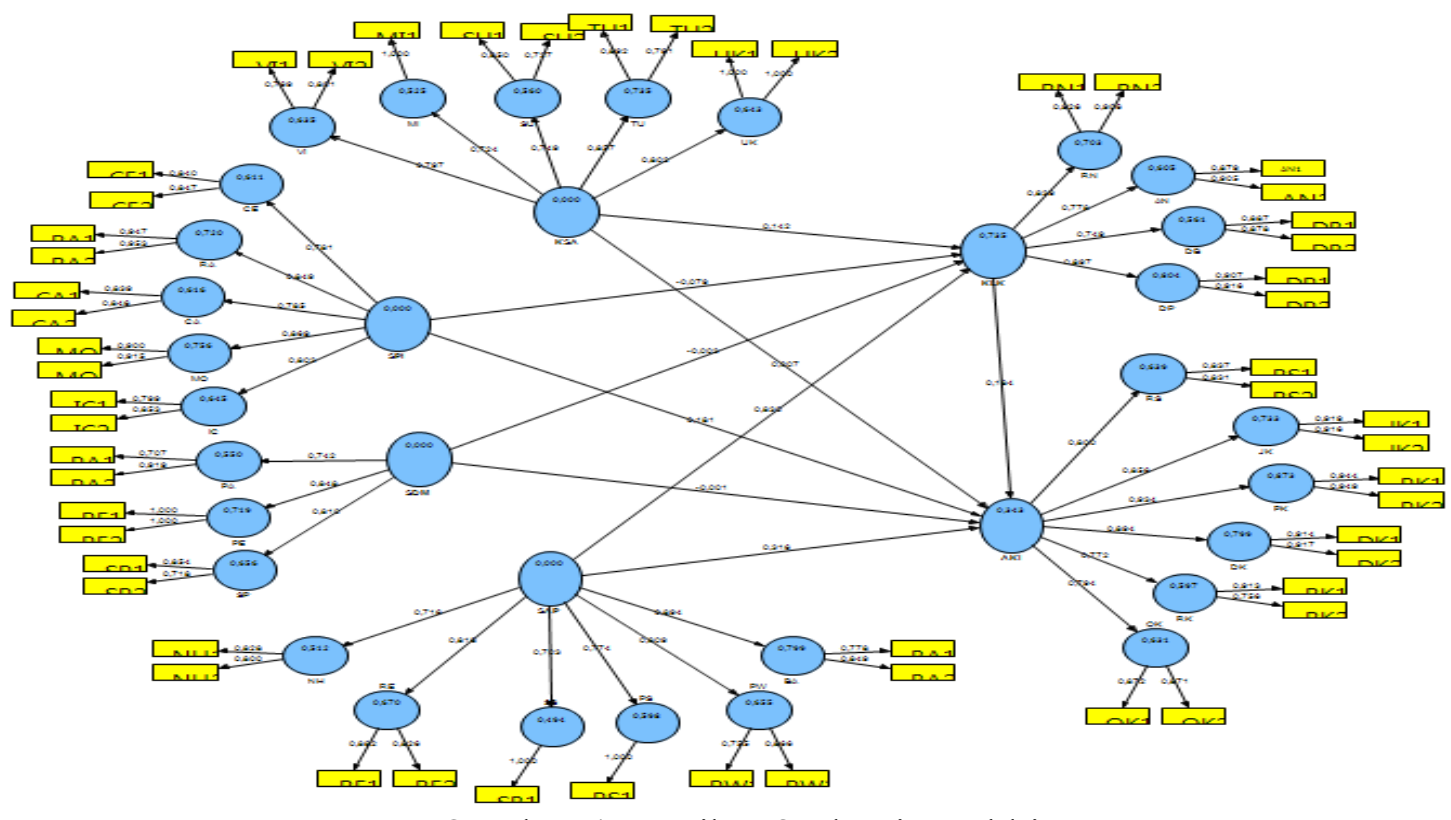

Gambar 1. Hasil PLS Algoritm Akhir

\section{Discriminant Validity}

Dalam penelitian ini metode yang dipakai adalah dengan melihat nilai cross loading. Nilai cross loading menunjukkan bahwa untuk semua konstruk > 0,5, sehingga persyaratan discriminant validity terpenuhi.

\section{Uji Reliabilitas}

Nilai Composite Reliability dan Cronbach's Alpha yang ditunjukkan pada Tabel 4.1 di bawah ini > 0,7, sehingga dapat disimpulkan bahwa semua indikator konstruk adalah reliabel atau memenuhi uji reliabilitas. 
Santha J. S., H. A. Rifa'i, L. Hamdani H. Jurnal InFestasi Vol.12, No.2, Desember 2016

Tabel 1. Hasil Goodness Of Fit Model

\begin{tabular}{ccccccc}
\hline & $\begin{array}{c}\text { Composite } \\
\text { Reliability }\end{array}$ & Akar AVE & $\begin{array}{c}\text { Cronbachs } \\
\text { Alpha }\end{array}$ & R-Square & $\begin{array}{c}Q \text { - } \\
\text { Square }\end{array}$ & Keterangan \\
\hline AKI & 0,939040 & 0,753212 & 0,927507 & 0,342593 & 0,6575 & Baik (fit) \\
KLK & 0,904262 & 0,737307 & 0,878020 & 0,734726 & 0,2653 & Baik (fit) \\
KSA & 0,887910 & 0,671334 & 0,857087 & & & Baik (fit) \\
SAP & 0,911938 & 0,668913 & 0,894536 & & & Baik (fit) \\
SDM & 0,848576 & 0,704290 & 0,779161 & & & Baik (fit) \\
SPI & 0,913667 & 0,753212 & 0,894114 & & & Baik (fit) \\
\hline
\end{tabular}

\section{Uji Model Struktural (Inner Model)}

Nilai $R$ square sebesar $0,67,0,33$, dan 0,19 untuk variabel endogen dalam model struktural mengindikasikan bahwa model kuat, moderat, dan lemah (Latan dan Ghozali, 2012:85). Nilai $R$ square KLK sebesar 0,734726 atau melebihi Rule of thumb R-square 0,67 berarti model tersebut menunjukan prediktor variabel kategori kuat. Nilai $R$ square AKI sebesar 0,3425 masuk dalam Rule of thumb $R$-square 0,33 sehingga model tersebut menunjukan prediktor variabel kategori moderat.

Nilai $Q$-Square predictive relevance untuk model struktural, mengukur seberapa baik nilai observasi dihasilkan oleh model dan juga estimasi parameternya. Nilai Q-square $>0$ menunjukkan model memiliki predictive relevance; sebaliknya jika nilai Q-Square $\leq 0$ menunjukkan model kurang memiliki predictive relevance. Nilai $Q$-square KLK menghasilkan 0,2652 >0 dan Nilai $Q$ square AKI $0,6575>0$ artinya kedua variabel tersebut memiliki predictive relevance atau model dalam penelitian ini layak untuk menjelaskan variabel endogennya.

Tabel 2. Uji Hipotesis berdasarkan Path Coefficient

\begin{tabular}{llllll}
\hline & Hipotesis & $\begin{array}{c}\text { Loading } \\
\text { Path }\end{array}$ & $\begin{array}{c}\text { T-statistics } \\
(\mid \text { O/STERR } \mid)\end{array}$ & $\begin{array}{l}\text { t-table } \\
\mathrm{a}=10 \%\end{array}$ & Kesimpulan \\
\hline KSA -> KLK & $\mathrm{H}_{1}$ & 0,142347 & 2,416882 & 1,66 & Diterima \\
KSA -> AKI & $\mathrm{H}_{2}$ & 0,006663 & 0,115281 & 1,66 & Ditolak \\
SPI -> KLK & $\mathrm{H}_{3}$ & $-0,078555$ & 1,602614 & 1,66 & Ditolak \\
SPI -> AKI & $\mathrm{H}_{4}$ & 0,181413 & 2,087135 & 1,66 & Diterima \\
SDM -> KLK & $\mathrm{H}_{5}$ & $-0,002927$ & 0,095267 & 1,66 & Ditolak \\
SDM -> AKI & $\mathrm{H}_{6}$ & $-0,000699$ & 0,016424 & 1,66 & Ditolak \\
SAP -> KLK & $\mathrm{H}_{7}$ & 0,830287 & 21,631566 & 1,66 & Diterima \\
SAP -> AKI & $\mathrm{H}_{8}$ & 0,316408 & 3,021868 & 1,66 & Diterima \\
KLK -> AKI & $\mathrm{H}_{9}$ & 0,184303 & 1,699243 & 1,66 & Diterima \\
\hline
\end{tabular}

Sumber : Output PLS, 2016

Pengaruh Kejelasan Sasaran Anggaran Terhadap Akuntabilitas Kinerja Instansi Pemerintah

Hasil menunjukkan bahwa Kejelasan Sasaran Anggaran (KSA) berpengaruh signifikan terhadap Kualitas Laporan Keuangan (KLK). Nilai koefisien jalur adalah positif sebesar 0,142347 yang menunjukkan bahwa arah hubungan antara Kejelasan Sasaran Anggaran (KSA) dengan Kualitas Laporan Keuangan (KLK) adalah positif yang artinya semakin baik Kejelasan Sasaran Anggaran (KSA) semakin baik pula Kualitas Lapoan Keuangan (KLK). 
Santha J. S., H. A. Rifa'i, L. Hamdani H. Jurnal InFestasi Vol.12, No.2, Desember 2016

Pengaruh Kejelasan Sasaran Anggaran
Terhadap Akuntabilitas
Instansi Pemerintah

Hasil pengujian hipotesis bahwa Kejelasan Sasaran Anggaran (KSA) berpengaruh tidak signifikan terhadap Akuntabilitas Kinerja Instansi Pemerintah (AKI). Hal ini sejalan dengan penelitian yang dilakukan Verbeeten (2008) yang menunjukkan bahwa sasaran anggaran yang jelas dan terukur dapat secara signifikan meningkatkan kinerja baik secara kuantitas maupun kualitas. Indudewi (2009), Kusumaningrum (2010), Karyanti (2010), Putra (2013) dan Nuraini serta Indudewi (2014) juga menyatakan Kejelasan Sasaran Anggaran, berpengaruh positif dan signifikan terhadap Akuntabilitas Kinerja Instansi Pemerintah. Namun hasil temuan ini sejalan dengan penelitian Darwanis dan Chairunnisa (2013) Kejelasan Sasaran Anggaran berpengaruh tidak signifikan terhadap Akuntabilitas Kinerja Instansi Pemerintah.

\section{Pengaruh Sistem Pengendalian Intern Terhadap Kualitas Laporan Keuangan}

Hasil pengujian hipotesis menunjukkan Sistem Pengendalian Intern (SPI) berpengaruh tidak signifikan terhadap Kualitas Laporan Keuangan (KLK) hasil penelitian tidak sejalan dengan penelitian Indriasari (2008), Sukmaningrum (2011), Yudianta dan Erawati (2012), Pamungkas (2012) Armando (2013), dan Darwanis dan Chairunnisa (2013) menunjukkan bahwa SPIP dan pengawasan keuangan berpengaruh signifikan positif terhadap nilai informasi laporan keuangan pemerintah. Namun sejalan dengan penelitian Arifianti (2011) sistem pengendalian intern tidak berpengaruh signifikan terhadap nilai pelaporan keuangan pemerintah.

\section{Pengaruh Sistem Pengendalian Intern Terhadap Akuntabilitas Kinerja Instansi Pemerintah}

Hasil menunjukkan bahwa Sistem Pengendalian Intern (SPI) berpengaruh signifikan terhadap Akuntabilitas Kinerja Instansi Pemerintah (AKI) Hasil penelitian ini sejalan dengan penelitian
Kusumaningrum (2010), Pamungkas (2012), Darwanis (2013), Nasir dan Oktari (2013), Kogulacumar (2013) dan Nuraini serta Indudewi (2014) yang menyatakan bahwa SPI berpengaruh terhadap Akuntabilitas Kinerja Instansi Pemerintah (AKI) namun berbeda dengan hasil penelitian Ajhar (2015) yang menyatakan bahwa SPI tidak berpengaruh terhadap Akuntabilitas Kinerja Instansi Pemerintah (AKI).

\section{Pengaruh Sumber Daya Manusia terhadap Kualitas Laporan Keuangan}

Hasil pengujian hipotesis menunjukkan Sumber Daya Manusia (SDM) berpengaruh tidak signifikan terhadap Kualitas Laporan Keuangan (KLK) Dengan mempertimbangkan penyimpangan dan temuan tersebut hasil penelitian ini tidak sejalan dengan penelitian yang dilakukan Arifianti (2011) yang menyatakan kualitas sumber daya manusia berpengaruh terhadap nilai pelaporan keuangan pemerintah daerah. Yudianta dan Erawati (2012) yang menyatakan bahwa SDM berpengaruh terhadap Kualitas Laporan Keuangan (KLK) namun sejalan dengan hasil penelitian yang dilakukan Indriasari (2008), dan Sukmaningrum (2011) yang menyatakan Sumber Daya Manusia tidak berpengaruh terhadap Kualitas Laporan Keuangan.

\section{Pengaruh Sumber Daya Manusia terhadap Akuntabilitas Kinerja Instansi Pemerintah.}

Hasil pengujian hipotesis menunjukkan Sumber Daya Manusia (SDM) berpengaruh tidak signifikan terhadap Akuntabilitas Kinerja Instansi Pemerintah (AKI), hasil penelitian ini sejalan dengan penelitian yang dilakukan Ajhar (2015) yang menyatakan bahwa SDM tidak berpengaruh terhadap Akuntabilitas Kinerja Instansi Pemerintah daerah kabupaten Dompu. model. Namun tidak sejalan dengan penelitian Gistyan (2014) menunjukkan kompetensi pegawai berpengaruh terhadap akuntabilitas kinerja instansi pemerintah 
Santha J. S., H. A. Rifa'i, L. Hamdani H. Jurnal InFestasi Vol.12, No.2, Desember 2016

Pengaruh Standar Akuntansi Keuangan terhadap Kualitas Laporan Keuangan

Hasil penelitian ini sejalan dengan penelitian Santoso (2008), Nugraheni dan Subaweh (2008), Zeyn (2011) dan Pamungkas (2012) bahwa Standar Akuntansi Pemerintahan (SAP) berpengaruh terhadap peningkatan Kualitas Laporan Keuangan (KLK). Berdasarkan uji hipotesis Standar Akuntansi Pemerintah (SAP) terhadap Kualitas Laporan Keuangan (KLK) adalah berpengaruh signifikan dengan arah hubungan positif yang artinya semakin baik penerapan Standar Akuntansi Pemerintah (SAP) semakin baik pula Kualitas Lapoan Keuangan (KLK).

\section{Pengaruh Standar Akuntansi Pemerintahan terhadap Akuntabilitas Kinerja Instansi Pemerintah.}

Hasil uji hipotesis menyatakan Standar Akuntansi Pemerintah (SAP) berpengaruh signifikan terhadap Akuntabilitas Kinerja Instansi Pemerintah (AKI) pada Dengan demikian hasil ini sejalan dengan penelitian Pamungkas (2012) yang menyatakan bahwa bahwa Penerapan SAP berpengaruh positif terhadap kualitas laporan keuangan dan akuntabilitas kinerja instansi pemerintah. Pengaruh Kualitas Laporan Keuangan terhadap Akuntabilitas Kinerja Instansi Pemerintah.

Hasil uji hipotesis menyatakan Kualitas Laporan Keuangan (KLK) berpengaruh signifikan terhadap Akuntabilitas Kinerja Instansi Pemerintah (AKI) Kedua variabel ini mempunyai saling hubungan yang kuat dalam pengelolaan keuangan dan anggaran. Hal ini sejalan dengan penelitian Santoso dan Pambelum (2008), Pamungkas (2012), Darwanis dan Chairunnisa (2013) yang menunjukkan bahwa penerapan akuntansi sektor publik dan laporan keuangan yang berkualitas berpengaruh signifikan terhadap akuntabilitas kinerja instansi pemerintah. Namun tidak sejalan dengan Asmoko (2012) yang menunjukkan tidak ada hubungan yang signifikan antara opini audit BPK atas LKKL dan hasil evaluasi LAKIP K/L.

\section{PENUTUP}

\section{Simpulan}

Penelitian ini menemukan adanya bukti pengaruh signifikan variabel Kejelasan Sasaran Anggaran (KSA) dengan variabel Kualitas Laporan Keuangan (KLK) dengan koefisien jalur positif yang artinya semakin baik Kejelasan Sasaran Anggaran (KSA) pada Satuan Kerja dibawah koordinasi Balai Besar MKG Wilayah III Denpasar-Bali maka semakin baik pula Kualitas Lapoan Keuangan (KLK).

Penelitian ini tidak dapat membuktikan pengaruh signifikan variabel Kejelasan Sasaran Anggaran (KSA) dengan variabel Akuntabilitas Kinerja Instansi Pemerintah (AKI) Artinya, Akuntabilitas Kinerja Instansi Pemerintah (AKI) akan meningkat tetapi tidak diikuti dengan peningkatan Kejelasan Sasaran Anggaran (KSA) hal ini menunjukkan bahwa terdapat faktor lain dalam model penelitian ini yang mempengaruhi Akuntabilitas Kinerja Instansi Pemerintah (AKI) secara langsung.

Penelitian ini menunjukkan koefisien jalur antara Sistem Pengendalian Intern (SPI) terhadap Kualitas Laporan Keuangan (KLK) bertanda negatif, artinya temuan ini menyalahi kerangka konseptual model. Dalam tataran ini aspek hasil pengujian signifikan dan tidak signifikan menjadi tidak bermakna lantaran temuan menyalahi kerangka konseptual model. Bila penyimpangan terhadap kerangka konseptual model diabaikan penelitian ini tidak dapat membuktikan pengaruh variabel Sistem Pengendalian Intern (SPI) dengan variabel Kualitas Laporan Keuangan (KLK) artinya meningkatnya Kualitas Laporan Keuangan (KLK) tidak ditentukan oleh Sistem Pengendalian Intern (SPI) yang dilaksanakan pada masing-masing Satuan Kerja tetapi terdapat faktor lain dalam penelitian ini yang secara langsung berpengaruh terhadap Kualitas Laporan Keuangan (KLK).

Penelitian ini menemukan adanya bukti pengaruh signifikan variabel Sistem Pengendalian Intern (SPI) dengan variabel Akuntabilitas Kinerja Instansi Pemerintah (AKI) dengan koefisien jalur positif yang artinya artinya semakin baik Sistem 
Santha J. S., H. A. Rifa'i, L. Hamdani H. Jurnal InFestasi Vol.12, No.2, Desember 2016

Pengendalian Intern (SPI) semakin baik pula Akuntabilitas Kinerja Instansi Pemerintah (AKI) pada Satuan Kerja dibawah koordinasi Balai Besar MKG Wilayah III Denpasar-Bali.

$$
\text { Penelitian ini menunjukkan }
$$

koefisien jalur antara Sumber Daya Manusia (SDM) terhadap Kualitas Laporan Keuangan (KLK) bertanda negatif, artinya temuan ini menyalahi kerangka konseptual model. Dalam tataran ini aspek hasil pengujian signifikan dan tidak signifikan menjadi tidak bermakna lantaran temuan menyalahi kerangka konseptual model. Bila penyimpangan terhadap kerangka konseptual model diabaikan penelitian ini tidak dapat membuktikan pengaruh variabel Sumber Daya Manusia (SDM) dengan variabel Kualitas Laporan Keuangan (KLK) artinya meningkatnya Kualitas Laporan Keuangan (KLK) tidak ditentukan oleh Sumber Daya Manusia (SDM).

Penelitian ini menunjukkan koefisien jalur antara Sumber Daya Manusia (SDM) terhadap Akuntabilitas Kinerja Instansi Pemerintah (AKI) bertanda negatif, artinya temuan ini menyalahi kerangka konseptual model. Dalam tataran ini aspek hasil pengujian signifikan dan tidak signifikan menjadi tidak bermakna lantaran temuan menyalahi kerangka konseptual model. Bila penyimpangan terhadap kerangka konseptual model diabaikan penelitian ini tidak dapat membuktikan pengaruh variabel Sumber Daya Manusia (SDM) dengan variabel Akuntabilitas Kinerja Instansi Pemerintah (AKI) artinya meningkatnya Akuntabilitas Kinerja Instansi Pemerintah (AKI) tidak ditentukan oleh Sumber Daya Manusia (SDM) yang ada pada masing-masing Satuan Kerja, tetapi terdapat faktor lain dalam model penelitian ini yang secara langsung berpengaruh terhadap Kualitas Laporan Keuangan (KLK).

Penelitian ini menemukan adanya bukti pengaruh signifikan variabel Standar Akuntansi Pemerintah (SAP) dengan variabel Kualitas Laporan Keuangan (KLK) dengan parameter koefisien positif, yang artinya semakin baik penerapan Standar Akuntansi Pemerintah (SAP) semakin baik pula
Kualitas Lapoan Keuangan (KLK) pada Satuan Kerja dibawah koordinasi Balai Besar MKG Wilayah III Denpasar-Bali

Hasil penelitian ini menemukan adanya bukti pengaruh signifikan variabel Standar Akuntansi Pemerintah (SAP) dengan variabel Akuntabilitas Kinerja Instansi Pemerintah (AKI) dengan koefisien jalur positif, yang artinya semakin baik penerapan Standar Akuntansi Pemerintah (SAP) semakin baik pula Akuntabilitas Kinerja Instansi Pemerintah (AKI) pada Satuan Kerja dibawah koordinasi Balai Besar MKG Wilayah III Denpasar-Bali.

Penelitian ini dapat membuktikan pengaruh variabel Kualitas Laporan Keuangan (KLK) terhadap Akuntabilitas Kinerja Instansi Pemerintah (AKI) artinya meningkatnya Kualitas Laporan Keuangan (KLK) diikuti dengan meningkatnya Akuntabilitas Kinerja Instansi Pemerintah (AKI) sebagai bentuk pertanggungjawaban pengelolaan keuangan negara.

\section{Implikasi Penelitian}

Hasil penelitian ini membawa implikasi baik, teoritis mengenai good governance, agensi teori dan akuntabilitas publik, bentuk pertanggungjawaban atau akuntabilitas organisasi sektor publik dan bermanfaat bagi pengambilan keputusan.

Melakukan perbaikan dan pengawasan secara intensif pada tahap perencanaan, pelaksanaan dan pertanggungjawaban keuangan negara. Memperbaiki pola rekrutmen pegawai, melakukan pemetaan tugas dan fungsi pegawai sesuai latar belakang pendidikan, penetapan peraturan mengenai rolling staf dan mutasi pejabat, serta meningkatkan kompetensi Sumber Daya Manusia di bidang penyusunan laporan keuangan dan laporan akuntabilitas kinerja melalui pendidikan dan pelatihan, dan meningkatkan pemahaman Standar Akuntansi Pemerintah (SAP).

\section{Keterbatasan Penelitian}

Penelitian ini mengandung beberapa keterbatasan yaitu: (1) Ruang lingkup penelitian ini hanya terbatas pada satuan kerja BMKG yang berada dibawah 
Santha J. S., H. A. Rifa'i, L. Hamdani H. Jurnal InFestasi Vol.12, No.2, Desember 2016

koordinasi Balai Besar MKG Wilayah III Denpasar-Bali, sehingga memungkinkan adanya perbedaan pada hasil penelitian dan kesimpulan apabila penelitian dilakukan pada satuan kerja BMKG di bawah Koordinasi Balai Besar MKG lainnya atau pada satuan kerja Kementerian yang lainnya. (2) Adanya ketidakakuratan pengukuran variabel terkait variabel eksogen SPI dan SDM yang menghasilkan temuan penyimpangan terhadap konseptual model. (3) Adanya kemungkinan mengeluarkan variabel-variabel eksogen yang memiliki koefisien jalur negatif dan mencari variabel eksogen lain sebagai pengganti agar menjadi positif.

\section{Saran}

Adapun saran-saran yang dapat dirumuskan oleh peneliti dalam penelitian ini antara lain, yaitu: (1) Penelitian selanjutnya dapat menambahkan atau mengganti obyek penelitian pada satuan kerja pada balai besar wilayah lainnya misalnya sampel dari dua atau tiga balai besar BMKG. (2) Untuk mencegah error of measurement variabel laten eksogen diperlukan perbaikan atau penyempurnaan dimensi dan pengukuran indikator variabel tersebut untuk mengatasi keterbatasan butir 2 diatas. (3) Penelitian ini kurang mengeksplorasi faktor-faktor lainnya yang diduga berpengaruh, misalnya variabel budaya organisasi, variabel temuan audit BPK, variabel pemanfaatan teknologi informasi dan variabel fraud untuk mengatasi keterbatasan pada butir 3 diatas.

\section{DAFTAR PUSTAKA}

Ajhar, 2015, Faktor-faktor yang mempengaruhi kesiapan SAP berbasis akrual dan akuntabilitas kinerja instansi pemerintah (Studi Empiris pada Pemerintah Daerah Kabupaten Dompu), Tesis Pascasarjana Universitas Mataram

Arfianti Dita, 2011, Analisis faktor-faktor yang mempengaruhi nilai informasi pelaporan keuangan pemerintah daerah (Studi pada satuan kerja perangkat daerah di kabupaten Batang), Universitas Diponegoro
Arifiyadi, Teguh, 2008, Konsep tentang Akuntabilitas dan Implementasinya di Indonesia. (serial online), Jul.Sept., [diakses 20 Mei 2015]. Tersedia: URL: http://blogs.depkominfo.go.id/itjen /2008/12/19/konsep-tentangakuntabilitas-dan-implementasinyadi-indonesia.

Arikunto S, 2006, Prosedur Penelitian Suatu Pendekatan Praktik, Ed Revisi VI, Penerbit PT Rineka Cipta, Jakarta.

Armando, Gerry, 2013. "Pengaruh Sistem Pengendaliaan Intern Pemerintah dan Pengawasan Daerah terhadap Nilai Informasi Laporan Keuangan Pemerintah Daerah pada SKPD di Kota Bukittinggi"

Asmoko Hindri, 2012, korelasi opini audit bpk atas lkkl dengan hasil evaluasi lakip $\quad K / L, \quad$ Balai Diklat Kepemimpinan BPPK

Atyanta Ramya, 2012, Analisis Opini BPK atas Laporan Keuangan Pemerintah Daerah (Studi Kasus pada Kabupaten $X$ di Jawa Timur)

Bastian, Indra, 2006, Akuntansi Sektor Publik Suatu Pengantar. Erlangga. Jakarta.

COSO. 2013. Internal Control Framework Resources.

Darwanis, dan S. Chairunnisa, 2013, Akuntabilitas Kinerja Instansi Pemerintah. Jurnal Telaah Riset \& Akuntansi 6 (2):150-174.

Kogulacumar Priya, 2013, Internal control system and its impact on the performance of the Sri Lanka Telecom limited in Jaffna District. International Journal of Advanced Computer Technology (IJACT). Volume 2, Number 6. Srilanka.

Djajadikerta, Hamfri, 2004, Perbandingan Pengendalian Intern dan Pengendalian Manajemen dalam Hubungannya dengan Agency Theory. Jurnal Bina Ekonomi 8(1): 1-109.

Ghozali, I, 2008, Structural Equation Modelling Metode Alternatif Dengan Partial Least Square (PLS). Badan Penerbit Universitas Diponegoro Semarang , 2014, Structural Equation Modelling Metode Alternatif Dengan 
Santha J. S., H. A. Rifa'i, L. Hamdani H. Jurnal InFestasi Vol.12, No.2, Desember 2016

Partial Least Square (PLS) edisi 4. Badan Penerbit Universitas Diponegoro Semarang

Gistyan, R. 2014, Akuntabilitas Keuangan, Kompetensi Pegawai, dan Akuntabilitas Kinerja. Jurnal Administrasi Pembangunan 2 (3): 227-360

Greiling, D, 2005, "Performance measurement in the public sector: the German experience", International Journal of Productivity and Performance Management, Vo1.54 No.7, pp. 551567.

Halim A, 2007, Seri Bunga Rampai Manajemen Keuangan Daerah : Akuntansi dan Pengendalian Pengelolaan Keuangan Daerah, UPP STIM YKPN, Yogyakarta.

Indriasari Desi, 2008, pemanfaatan teknologi informasi dan pengendalian intern akuntansi berpengaruh positif signifikan terhadap keterandalan pelaporan keuangan pemerintah daerah, sedangkan kapasitas sumber daya manusia tidak berpengaruh. Kedua, kapasitas sumber daya manusia dan pemanfataan teknologi informasi berpengaruh positif signifikan terhadap ketepatwaktuan pelaporan keuangan pemerintah daerah, Universitas Gadjah Mada.

Indudewi Dian, 2009, Pengaruh sasaran jelas dan terukur, insentif, desentralisasi, dan pengukuran kinerja terhadap kinerja organisasi (studi empiris pada skpd dan bumd kota semarang, tesis, Univ.Diponegoro.

Jensen, and W. H. Meckling, 1976. Theory of the Firm: Managerial behavior, agency costs and ownership structure. Journal of financial Economics $3: 305-360$.

Jogiyanto, 2011. Konsep dan Aplikasi Structural Equation Modelling Berbasis Varian dalam Penelitian Bisnis. UPP STIM YPKN. Yogyakarta

Kusumaningrum Indriaswari, 2010, Pengaruh kejelasan sasaran anggaran, pengendalian akuntansi dan sistem pelaporan terhadap akuntabilitas kinerja instansi pemerintah provinsi jawa tengah, Tesis. Universitas Diponegoro.

LAN, BPKP, 2003, Pengukuran Kinerja Instansi Pemerintah, Modul Sosialisasi Sistem Akuntabilitas Kinerja Instansi Pemerintah (AKIP). Lembaga Administrasi Negara. Jakarta.

Latan, Hengky dan Imam Ghozali, 2012, Partial Least Square : Konsep teknik dan aplikasi SmartPLS 2.0M3.Semarang : Badan Penerbit Universitas Diponegoro.

Mahmudi, 2005, Manajemen Kinerja Sektor Publik, UPP AMP YKPN,Yogyakarta.

Mardiasmo, 2006, Perwujudan Transparansi dan Akuntabilitas Publik Melalui Akuntansi Sektor Publik: Suatu Sarana Good Governance, Jurnal Akuntansi Pemerintahan Vol.2 No.1. , 2009. Akuntansi Sektor Publik. Penerbit Andi.Yogyakarta

Martiningsih, Rr Sri Pancawati, 2009, Studi Kebutuhan Informasi Pengguna Laporan Keuangan Pemerintah. Simposium Nasional Akuntansi XII Palembang 2009

Milal Zainul Ahmad, 2012, Makna opini audit WTP bagi kementrian / lembaga (studi kasus pada kementrian sosial, Universitas Brawijaya

Nasir, A dan Oktari, R, 2013, Pengaruh Pemanfaatan Teknologi Informasi dan Pengendalian Intern terhadap Kinerja Instansi Pemerintah (Studi Pada Satuan Kerja Perangkat Daerah Kabupaten Kampar ) , Universitas Riau.

Nugraha, M.Qudrat, 2007, Manajemen Strategik Organisasi Publik, Jakarta: Penerbit Universitas Terbuka

Nugrahaeni, Purwaniati dan Imam Subaweh, 2008, Pengaruh Penerapan Standar Akuntansi Pemerintah terhadap Kualitas Laporan Keuangan. Jurnal Ekonomi dan Bisnis, 13(1).

Nuraini, Indudewi Dian, 2014, Pengaruh Kejelasan Sasaran Anggaran, Pengendalian Akuntansi, dan Sistem Pelaporan terhadap Akuntabilitas Kinerja Instansi 
Santha J. S., H. A. Rifa'i, L. Hamdani H. Jurnal InFestasi Vol.12, No.2, Desember 2016

Pemerintah

Kabupaten

Brebes.Universitas Semarang.

Noerdiawan, Deddi, 2008. Akuntansi Pemerintahan. Jakarta: Salemba Empat

Pamungkas Bambang, 2012, Pengaruh Penerapan Akuntansi Sektor Publik dan pengawasan terhadap Kualitas Laporan Keuangan dan implikasinya terhadap akuntabilitas kinerja Instansi Pemerintah, Jurnal Ilmiah Ranggading, Vol.12 No.2.

Riantiarno, Reynaldi dan Azlina, Nur, 2011, Faktor-faktor yang Mempengaruhi Akuntabilitas Kinerja Instansi Pemerintah (Studi pada Satuan Kerja Perangkat Daerah Kabupaten Rokan Hulu). Jurnal Pekbis, Vol: 3, No.3.

Putra, Deki, 2013, Pengaruh Akuntabilitas Publik dan Kejelasan Sasaran Anggaran terhadap Kinerja Manajerial Satuan Kerja Perangkat Daerah (Studi Empiris pada Satuan Kerja Perangkat Daerah Kota Padang). Universitas Negeri Padang.

Santoso, Pambelum, 2008, Pengaruh Penerapan Akuntansi Sektor Publik Terhadap Akuntabilitas Kinerja Instansi Pemerintah Dalam Mencegah Fraud. Jurnal Administrasi Bisnis ,Vol.4, No.1: hal. 14-33, (ISSN:0216-1249) 2008

Sudarmanto, 2014, Kinerja dan Pengembangan Kompetensi SDM : Teori, Dimensi Pengukuran, dan Implementasi dalam Organisasi. Pustaka Pelajar. Yogyakarta

Sugiyono, 2004, Metode Penelitian Bisnis, CV. Alfabeta, Bandung.

2013, Metode Penelitian Kuantitatif, Kualitatif dan R\&D. Alfabeta. Bandung.

Sukmaningrum, T, dan Harto, P, 2011, Analisis Faktor-Faktor yang Mempengaruhi Kualitas Informasi Laporan Keuangan Pemerintah Daerah (Studi Empiris pada Pemerintah Kabupaten dan Kota Semarang)

Syafrial, 2009, Pengaruh Ketepatan Skedul Penyusunan Anggaran, Kejelasan Sasaran Anggaran, dan Partisipasi Penyusunan Anggaran Terhadap Kinerja Manajerial Satuan
Kerja Perangkat Daerah. Tesis. Universitas Sumatera Utara

Karyanti, Dwi, Tutik, 2010, Pengaruh kejelasan sasaran, desentralisasi, dan sistem pengukuran terhadap kinerja organisasi sektor publik (studi empiris di politeknik negeri semarang). Universitas Diponegoro.

Verbeeten, Frank H.M. 2008, "Performance management practices in public sector organizations: impact on performance", Accounting, Auditing \&Accountability Journal, Vol.21 No.3, pp.427-454.

Widoyoko, Eko Putro, 2012, Teknik Penyusunan Instrumen Penelitian. Pustaka Pelajar, Yogyakarta

Yudianta, Erawati, 2012, Pengaruh Sumber Daya Manusia Teknologi Informasi dan Pengendalian Intern terhadap Kualitas Laporan Keuangan, E-Jurnal Akuntansi Universitas Udayana.

Zeyn, E., 2011, Pengaruh Penerapan Good Governance dan Standar Akuntansi Pemerintah terhadap Akuntabilitas Keuangan, Jurnal Trikonomika 2011 , Undang-Undang Nomor 17 Tahun 2003 tentang Keuangan Negara , Undang-Undang Nomor 1 Tahun 2004 tentang Perbendaharaan Negara Undang-Undang Nomor 15 Tahun 2004 tentang Pemeriksaan dan Pertanggungjawaban Keuangan Negara

, Peraturan Pemerintah Nomor 101 Tahun 2000 tentang Pendidikan dan Pelatihan Jabatan Pegawai Negeri Sipil. , Peraturan Pemerintah Nomor 8 Tahun 2006 tentang Pelaporan Keuangan dan Kinerja Instansi Pemerintah. Peraturan Pemerintah Nomor 60 Tahun 2008 tentang Sistem Pengendalian Internal Pemerintah , Peraturan Pemerintah Nomor 71 Tahun 2010 tentang Standar Akuntansi Pemerintah. , Peraturan Pemerintah Nomor 29 Tahun 2014 tentang Sistem 
Santha J. S., H. A. Rifa'i, L. Hamdani H. Jurnal InFestasi Vol.12, No.2, Desember 2016

Akuntansi Kinerja Instansi

Pemerintah. Instruksi Presiden Republik Indonesia Nomor 7 Tahun 1999 tentang Akuntabilitas Kinerja Instansi Pemerintah. Keputusan Kepala Lembaga Administrasi Negara Nomor 239/IX/6/8/2000 tentang Perbaikan Pedoman Penyusunan Pelaporan Akuntabilitas Kinerja Instansi Pemerintah.
Peraturan Menteri Pendayagunaan Aparatur Negara Reformasi Birokrasi Nomor 12 Tahun 2015 tentang Pedoman Evaluasi Implementasi Sistem Akuntabilitas Kinerja Instansi Pemerintah. Peraturan Direktur Jenderal Perbendaharaan Nomor 42/PB/2014 tentang Pedoman Pedoman Penyusunan Laporan Keuangan Kementerian / Lembaga. 